\title{
Development of infrastructure of support of small and medium business
}

\author{
Asiiat Mottaeva ${ }^{1}$, Natalia Gritsuk $^{2, *}$ \\ ${ }^{1}$ Moscow State University of Civil Engineering, Yaroslavskoe shosse, 26, Moscow, 129337, Russia \\ ${ }^{2}$ Vyatka State University, Moskovskaya str., 36, Kirov, 610000, Russia
}

\begin{abstract}
Support small business development is a high priority of state regulation of economy. The article examines and analyzes the basic directions in infrastructure support of the enterprises of small and medium enterprises, contributing to increase the contribution of this sector to the economy of the country. In Russia small business is a much smaller place and plays a minor role in the development of economic relations. This is reflected in the development of economic relations both domestically and within international relations. Flexibility in economic relations of Russian companies on the world stage is quite small. Foreign trade operations in most cases are implemented by big businesses and small businesses in Russia are active only within their regions. Infrastructure support of development of small business in Russia is a task that is not solved until now. Every leader coming to power, determines the necessity of development of small business, the set of tasks for development of the company forced to return attention to big business. Each stage of development of infrastructure should be consistent, should carry out their tasks. AT the present stage of development of the infrastructure for small businesses, we see a separate unrelated decisions that do not represent a complete concept. In this regard, it is necessary to identify those factors that need to be developed first and foremost in the development of infrastructure.
\end{abstract}

\section{Introduction}

Problems and prospects of development of small and medium enterprises (SMEs) in Russia in recent years has become more attention is paid that is related to search of reserves of growth of economy in the conditions of continuing its stagnation. This is largely due to the introduction of sanctions against Russia from foreign countries and companies. Created in connection with this difficulty attracted the attention of scientists and specialists to the problems of domestic entrepreneurship, including SMEs, faced with the goal to reach a level comparable with leading foreign countries.

\footnotetext{
*Corresponding author: grinata777@rambler.ru
} 


\section{Methods}

In order to achieve these goals, it is necessary in the coming years to undertake the following:

- assist in the implementation of measures to improve market infrastructure, which will be focused on the creation and development of new SMEs;

- to implement special programmes to support a promising competitive small and medium enterprises;

- to implement modern and efficient financial tools for business development;

- to maintain existing financing institutions to create the most favorable conditions for their existence;

- to develop existing and create new organizational structures such as business incubators, technological parks, innovative-technological parks, technology transfer centers;

- improve the regulatory framework in order to eliminate the existing administrative barriers for future development of SMEs in Russia and to prevent the emergence of new problems;

- to implement the rules of legislation that determine the possibility of participation of small and medium-sized businesses in public tenders;

- to increase the access of domestic producers in the face of SMEs to real estate belonging to state or municipal ownership.

\section{Results}

Consider in more detail key areas of implementation of the state policy of development of infrastructure of support of small and medium-sized businesses.

1. The creation of special economic zones (SEZ). Special economic zone (SEZ) is a territory with special legal status, on which there are favorable economic conditions for implementation of activities for domestic or foreign entrepreneurs. Legal entities that have their management on the territory of SEZ, referred to as its residents. Expressing this mode is a special legislation which regulates the activities of businesses in the SEZ, and covers such issues as customs regulations; taxation; licensing; visas; banking; property and collateral relations (including rights of land ownership); the granting of concessions; management of a free zone. A certain specificity in the SEZ can also have acts of labour law and social security law.

In recent theoretical works devoted to the problems of the SEZ, their essence is interpreted more widely: they are defined as a tool for selective reduction of state intervention in economic processes, i.e. this organizational form is most attractive for the functioning of the structures of SMEs. This formulation of the concept of the SEZ covers the whole range of phenomena related to the operation of the preferential treatment of management. In this approach, a special area is "not only and not so much a separate geographical territory, but rather part of the national economic space, where we have introduced and applied a system of incentives that is not used in other parts of the world" [1-9].

The establishment of the SEZ - efficient direction of development of SMEs in the regions, focused generally on specific priority economic objectives, implementation of strategic programs and projects for the development of SMEs. However, as practice shows, the system of benefits established in the SEZ are sufficiently individual and is closely connected with ongoing on its territory programs

2. Participation in tenders for the supply of goods and services for state needs. 
The key problem for small and medium enterprises is the low level of demand for their products and services. According to the Ministry of economic development, the real solution to this problem is to ensure the availability of state and municipal orders for small and medium businesses. To date in this direction, efforts have been made: the legislation on public procurement provides for quotas for SMEs on procurement of state corporations and natural monopolies; develop electronic auctions, which is provided with real participation of small and medium business in the supply of products for state and municipal needs.

\section{Discussion}

To assess the effectiveness of the proposal in Table 1 presents the data values of public procurement performed for subjects of small and average business.

Table 1. Main indicators of tendering for the supply of goods, performance of works (services) for state needs among small and medium-sized business.

\begin{tabular}{|c|c|c|c|c|}
\hline \multirow{2}{*}{ Period } & \multicolumn{2}{|c|}{ The number of contracts } & \multicolumn{2}{c|}{ Value of contracts } \\
\cline { 2 - 5 } & just & in \% of total & million. rub. & in \% of the total cost contracts \\
\hline 2011 & 129805 & 15.2 & 93059 & 3.0 \\
\hline 2012 & 122773 & 13.2 & 106718 & 3.1 \\
\hline 2013 & 156908 & 14.2 & 117738 & 2.7 \\
\hline 2014 & 185208 & 13.9 & 126757 & 3.1 \\
\hline 2015 & 310622 & 22.7 & 226500 & 6.1 \\
\hline
\end{tabular}

The table shows that in 2015 the number of state contracts concluded with SMEs, grew by $41 \%$, and the amount of contracts increased by $40.6 \%$ to 488 billion This result is the most significant among all other measures of support of small and medium business. The state is interested in extending the state (municipal) order and order of the natural monopolies and state corporations to small and medium-sized businesses.

The high level of competition for lucrative public order demands from small and medium-sized companies understanding of the mechanism of electronic trading. In accordance with the legislation of the state and municipal purchases are made mainly through electronic auctions. The Russian government identified five official electronic marketplaces for public procurement (http://www.zakazrf.ru/, http://etp.roseltorg.ru/, http://www.sberbank-ast.ru/, http://www.etp-micex.ru, http://www.rts-tender.ru/). Improving the competitiveness of SMEs through subsidies to exporters.

1. In connection with Russia's accession to the WTO has increased the urgency of the task of increasing the competitiveness of domestic SMEs. In order to stimulate the activity of SMEs based on the increase in demand for its products by increasing its competitiveness, small and medium-sized companies exporting their products, given financial support at the expense of means of budgets of all levels. In the framework of this program subsidies already received several hundred companies.

2. The increased availability of office and industrial real estate. Following the direction of the state support to SMEs related to improving the availability of office and manufacturing space for small and medium-sized businesses. The solution to this problem is to provide small and medium-sized companies pre-emptive rights of the leased premises. It is also planned to form a list of property for its target of granting leases to SMEs in all regions of Russia. By results of work in this direction, according to the Ministry of economic 
development, should see more than 5000 new owners - small and medium business $[3,8,11,13]$.

3. The availability of technological infrastructure. Government planned to facilitate access for SMEs to real estate, which include the technological infrastructure (electricity, gas, and utility systems). Currently, a third of the costs of SMEs accounted for costs on access to technological infrastructure. To reduce the share of such costs and their optimization is possible due to the use of the model agreement, reducing tariffs on accession, the introduction of an independent examination.

4. The development of a system of grants to support entrepreneurs. First and foremost, the grant support should be provided for such categories of SMEs as innovative companies; companies which carry out the modernization of production and export of produced goods; aspiring entrepreneurs.

In world practice, the most popular such forms of grant support for micro-Finance and training programs. Currently beginners with small innovative companies that are created at higher education institutions, allocated a grant in the amount of 0.5 million rubles for a single legal entity [3,10-15].

In all constituent entities of the Russian Federation to support young entrepreneurs through a system of grants. A necessary condition for providing such support to the beginners is to take courses on the basics of taxation, law and management. At the same time, priority will be given to short courses lasting up to 100 hours. Development and improvement of programs of business education for aspiring entrepreneurs will help to increase the "survival rate" of SMEs in the most difficult of the first three years of operations.

5. Increased financial support. One important task is to increase financial support to SMEs. With the help of Federal and regional programs of support of small and average business, provided by subsidizing the cost of interest payment for loans of SMEs. According to the Ministry of economic development of Russia, it is planned to double the capitalization of regional guarantee funds of the guarantors by SME loans, including through the introduction of a new mechanism of state guarantees. Also creates a network of private equity funds and in SME Fund investments in the innovation development of SMEs.

6. 8. Reduction in the administrative burden on business.

A result of the adoption of the Law №294-FZ "On protection of the rights of entrepreneurs when exercising state control" has the opportunity to reduce the number of unplanned inspections of businesses, to reduce the administrative burden on entrepreneurs. Work on reduction of administrative barriers, preventing the emergence of new barriers has been identified as a priority in the activities of state bodies.

\section{Conclusions}

In conclusion it can be concluded that the policy used by the state in respect of small and medium business, piecemeal. Often decisions made by the government contradict each other. However, over the past few years almost all the most valuable ideas and initiatives of the business community (the tax holiday, the economic Amnesty, regulatory holidays), the state supported and implemented. This demonstrates the progress in relations between the authorities and the business community that will in the next few years to reverse the downward trend in the number of small and medium enterprises. 


\section{References}

1. A. Fayol, G. Emerson, F. Taylor, G. Ford, The Management of science and art (Respublika, Moscow, 1992)

2. R. Hunt, Strategic management 3, 46-48 (2011)

3. O.N. Bocharova, Socio-economic phenomena and processes 10, 98-111 (2013)

4. V.F. Bogachev, The World of Economics and law 1, 7-15 (2012)

5. N. Smorodinskaya, D. Kapustin, Questions of economy 12, 32 (2012)

6. N. P. Veretennikov, R. G. Leont'ev, Regional'nye korporacii v sfere telekommunikacij: organizacionnyj aspekt (Vladivostok, 1999)

7. A. Mottaeva, MATEC 73, 07020 (2016)

8. A.B. Mottaeva, A. Zheltenkov, I. Stukanova, S. Ryabichenko, S. Zhuk, MATEC 73, 07026 (2016)

9. An.B. Mottaeva, As.B. Mottaeva, International Journal of Applied Engineering Research 1, 10- 23 (2015)

10. An.B. Mottaeva, As.B. Mottaeva, International Journal of Applied Engineering Research 1, 11- 9 (2016)

11. E. Stein, N. Taskaeva, E. Chibisova, Procedia Engineering 165, 1410-1416 (2016)

12. T. Miroshnikova, N. Taskaeva, MATEC 73, 123284 (2016)

13. A. Pimenova, S. Kuzmina, N. Morozova, A. Mottaeva, MATEC 73, 07018 (2016)

14. L.V. Nikolova, D.G. Rodionov, A.B. Mottaeva, International Journal of Economics and Financial Issues 6(S3), 1-7 (2016)

15. A.I. Shlafman, Vestnik Murmanskogo gosudarstvennogo tehnicheskogo universiteta 15-1, 250-253, 2012 